Document downloaded from:

http://hdl.handle.net/10251/78936

This paper must be cited as:

Usó, M.; Jantus Lewintre, E.; Sirera Pérez, R.; Bremnes, RM.; Camps, C. (2014). miRNA detection methods and clinical implications in lung cancer. Future Oncology. 10(14):22792292. doi:10.2217/FON.14.93.

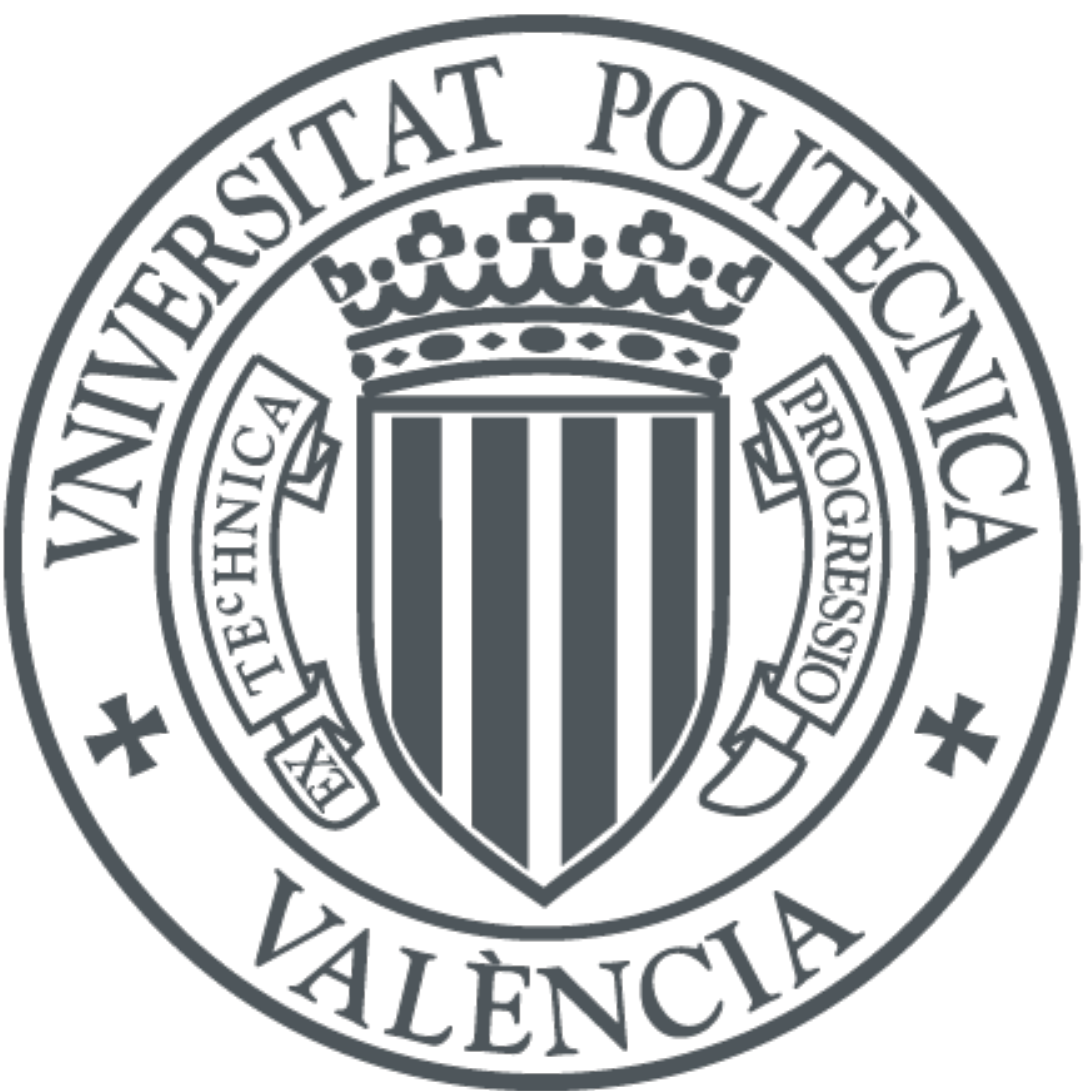

The final publication is available at

Copyright Future Medicine

Additional Information 


\section{Micro RNAs detection methods and clinical implications in lung cancer}

Marta Usó ${ }^{1}$, Eloisa Jantus-Lewintre ${ }^{2}$, Rafael Sirera ${ }^{3}$, Roy M. Bremnes ${ }^{4}$ and Carlos Camps $s^{5,6, \S}$

${ }^{1}$ Molecular Oncology Laboratory, Fundación para la Investigación del Hospital General Universitario de Valencia. Av. Tres Cruces s/n, 46014 Valencia, Spain. Tel: + 34961972 000, ext. 52050; Fax: +34 961972 151; E-mail: uso_mar@gva.es

${ }^{2}$ Molecular Oncology Laboratory, Fundación para la Investigación del Hospital General Universitario de Valencia. Av. Tres Cruces s/n, 46014 Valencia, Spain. Tel: + 34961972 000, ext. 52050; Fax: +34 961972 151; E-mail: jantus_elo@gva.es

${ }^{3}$ Department of Biotechnology, Universitat Politècnica de València, Camí de Vera, s/n 46022 Valencia, Spain. Tel.: +34 9638795 56, ext. 19 556; +34 9638774 24; E-mail: rsirera@btc.upv.es

${ }^{4}$ Department of Clinical Medicine, University of Tromso and Department of Oncology, University Hospital North Norway, Tromso N-9037 Norway Tel: +47 776 26807, Fax: +47 776 26779; E-mail: roy.bremnes@uit.no

${ }^{5}$ Medical Oncology Department, Consorcio Hospital General Universitario de Valencia. Av. Tres Cruces s/n, 46014 Valencia, Spain and ${ }^{6}$ Department of Medicine, Universitat de Valencia, Av. Blasco Ibáñez 13, 46010 Valencia, Spain. Tel.:+34 9619721 84; Fax: +34 961 9721 51, E-mail: camps_car@gva.es 
${ }^{\S}$ Corresponding author: Carlos Camps

Medical Oncology Department, Consorcio Hospital General Universitario de Valencia and Department of Medicine, Universitat de Valencia, Av. Blasco Ibáñez 13, 46010 Valencia, Spain. Tel.:+34 9619721 84; Fax: +34 9619721 51, E-mail: camps_car@gva.es 


\section{ABSTRACT}

Lung cancer is the leading cause of cancer death worldwide. Therefore, advances in diagnosis and treatment of the disease are urgently needed. MicroRNAs (miRNAs) are a family of small non-encoding RNAs that regulate gene expression at the transcriptional level. MiRNAs have been reported to be deregulated and to play a critical role in different types of cancer, including lung cancer. Thus, miRNA profiling in lung cancer patients has become the core of several investigations. To this end, the development of a multitude of platforms for miRNA-profiling analysis has been essential. This review focuses on the different technologies available to assess miRNAs and the most important results obtained to date in lung cancer.

\section{KEYWORDS:}

microRNA, lung cancer, biomarker, microRNA-profiling, diagnosis, prognosis 


\section{INTRODUCTION}

Lung cancer is the leading cause of cancer-related death worldwide [1]. The disease can be classified into two subgroups based on histology: Non-small cell lung cancer (NSCLC) (85\%) and small cell lung cancer (SCLC) (15\%) [2]. Five year survival remains poor (15\%) [3], mainly because the tumor has already developed local or distant metastasis at the time of diagnosis [4]. Despite the existence of several distinct tumor phenotypes, therapeutic decisions are mainly based on clinical features such as stage or performance status. This highlights the need for new biomarkers which can be used in clinical practice, not only as diagnostic or/and prognostic tools but also as therapeutic targets.

MicroRNAs (miRNAs) are a family of small, highly conserved non-encoding RNAs of 1825 nucleotides in length that were discovered in the early 1990s by Victor Ambros and colleagues in Caenorhabditis elegans [5]. Long primary transcripts (pri-miRNA) are transcribed by RNA polymerase $I I$ and then sequentially processed by the ribonucleases Drosha and Dicer [6] (Figure 1). MiRNAs are important regulators of genes related to fundamental processes such as cellular proliferation, differentiation, development or apoptosis. These small molecules regulate gene expression binding the $3^{\prime}$ region of target messenger RNA (mRNA), thereby inhibiting translation and promoting degradation of mRNA $[7,8]$.

Altered miRNA profiles have been observed in virtually every tumor type when compared with normal cells or tissue. It appears they act on both oncogenes and tumor suppressor genes [9]. This phenomenon was first observed in chronic lymphocytic leukaemia (CLL), when Calin et al. demonstrated that the gene cluster 
containing miR-15 and miR-16 was deleted in most CLL patients [10]. In lung cancer, miRNA expression patterns have been extensively studied and it has been proved that they are involved in both lung cancer development and progression [11]. Early on, studies pointed towards a relationship between lung cancer and miRNAs. A decade ago, Takamizawa et al. observed that reduced expression of let-7, a negative regulator of the RAS oncogene, was significantly associated with shortened survival in NSCLC patients [12]. More recently, overexpression of miR-221 and miR-222 has been associated with aggressive NSCLC due to their ability to enhance cellular migration by targeting PTEN [13]. Similarly, the miR-34 family has been related to tumor proliferation through the p53 pathway and relapse of NSCLC patients [14]. Some of the most relevant studies regarding the role of miRNAs in lung cancer are summarized in Table 1.

There is growing evidence to indicate that miRNAs have adequate characteristics for a biomarker: i) they display unique expression profiles in different human cancers, ii) due to their resistance to ribonucleases, miRNAs are more stable than mRNAs, and iii) detection and quantification of miRNAs can be efficiently assessed by various platforms and matrices $[15,16,17]$. Presently, approaches such as microarrays, quantitative reverse transcriptase PCR (qRT-PCR), next generation sequencing (NGS) and in situ hybridization (ISH), (described in Table 2) have been used in order to analyze miRNA expression in lung cancer samples.

We performed a comprehensive search of the literature using MEDLINE for original and review articles related to the terms "microRNAs", "microRNAs detection" and "microRNAs and lung cancer" (last update January 2014). We also reviewed the 
bibliographies reported in these articles to complete the search. Only articles published in English were included. The following sections give an overview of the different methods used for isolation, detection and quantification of miRNAs in various biological samples from lung cancer patients. This is not intended to be an exhaustive and detailed description of the methodological aspects of all these topics, which have been covered in several recent articles. Rather, the intention is to provide an updated overview regarding the value of different approaches in miRNA analysis in clinical specimens that can be used as tools for the identification of new biomarkers and therapeutic targets in lung cancer. In this regard, a summary of the most relevant miRNAs discussed in this review and their clinical implications in lung cancer is provided in Table 3

\section{MICRORNA ISOLATION AND PURIFICATION}

In general, the accuracy and reliability of different detection methods depend on the quality and abundance of miRNAs. Consequently, use of an appropriate RNA isolation method is important. High quality miRNA can be isolated from tissue, cells or blood using the same principles as for isolation of total RNA, with slight modifications. Commercially available reagents such as guanidinium thiocyanate and purification columns with silica-based membranes are generally used. It has also been documented that miRNA stability and integrity are preserved in formalin-fixed, paraffin-embedded (FFPE) tissues [16], and can be successfully isolated [18]. Since the technique for collection is non-invasive, peripheral blood has been widely used for miRNA isolation. Not only whole blood, but also serum and plasma samples have proved to be useful, mainly because of the high stability of miRNAs isolated from these sources. In fact, 
tumors appear to release vesicular structures (exosomes), which have been proved to contain and protect miRNAs, into peripheral circulation [19]. Since these exosomes can be isolated from minimally invasive samples, and they contain stable miRNAs, they have been suggested as surrogate markers for biopsy profiling.

During manipulation and isolation procedures it is pivotal to avoid the action of RNase enzymes that could partially or totally digest the purified miRNA fraction. Consequently, before proceeding with the analysis, it is recommended to assess the integrity of RNA extracted and therefore automated capillary electrophoresis are widely used for detecting the presence or absence of RNA degradation products. This method provides a RNA integrity number (RIN) which is calculated by a software algorithm and which depends on the entire electrophoretic trace of the RNA sample. Some authors have suggested that a minimal RIN of 7 should be exceed in order to obtain reliable miRNA-analysis results [20]. Due to low molecular weight and low abundance of miRNAs, which can limit the method's sensitivity in some cases, small RNA (sRNA) enrichment step is recommended when using miRNA detection methods such as microarray platforms and NGS [21,22]. Different methods, such as ultra-fast denaturing polyacrylamide gel electrophoresis (PAGE) purification of nucleic acids followed by ethanol precipitation [23], or commercial kits that included silica-based column systems can be used for this purpose.

\section{MICRORNA DETECTION METHODS AND CLINICAL CORRELATES IN LUNG CANCER}

\subsection{Analysis in biological specimens.}

\subsubsection{Quantitative real-time PCR ( $q R T-P C R$ )}


qRT-PCR technology is considered a "gold standard" in the quantification of gene expression. Some of its major advantages are speed, sensitivity and the low amount of RNA required. The first step when analysing miRNA by qRT-PCR is the conversion of RNA into complementary DNA (cDNA). Currently, two different approaches can be used for reverse transcription (RT) of miRNAs: miRNA universal RT or miRNA-specific RT. In universal RT, miRNAs are tailed with a common sequence and a universal PCR primer is used to initiate elongation [24]. For miRNA-specific RT, miRNA specific primers are used composed by a $3^{\prime}$-end complementary to the miRNA and a 5 '-end that can either be a linear structure or a stem-loop [25]. Even though linear structures are simpler to design, stem-loop structures are usually more useful because they increase the specificity of the reaction, reduce annealing of the primer to the pre- and pri-miRNAs and avoid binding to double-stranded genomic DNA (dsDNA) molecules [26]. In cases with limited initial material or a large number of miRNAs to be analyzed, different approaches are recommended: miRNA universal RT, multiplex RT using a pool of stem-loop primers [27], or the addition of a cDNA pre-amplification step [28].

qRT-PCR works by detecting the amount of fluorescent molecules, which directly correlates with the quantity of DNA present in the reaction [29]. Although several fluorescent technologies exist, SYBR Green and TaqMan hydrolysis probes are the most suitable methods for miRNA analyses. SYBR Green is an intercalating fluorescent dye that binds all dsDNA, even non-specific PCR products including primer-dimers [30]. These non-specific bindings limit accuracy of the detection method; hence the use of melting point analysis, also known as dissociation curve, is pivotal when using SYBR Green. Another option is hydrolysis probes which consist of a fluorescent reporter on 
the $5^{\prime}$-end and a quencher on the $3^{\prime}$-end, which prevents emission of fluorescence by proximity. During PCR, the probe and the primers anneal to the target sequence and the Taq polymerase extends the primer upstream of the probe. If the probe is bound to the correct target, the Taq polymerase hydrolyses the probe, resulting in increased fluorescence proportional to the amount of product generated [24].

The reliability and reproducibility of the analyses can be improved using endogenous control genes, expression of which should remain as stable as possible in various tissues and conditions [25]. To date, there is no consensus on which endogenous control genes should be used when working with miRNA and, therefore, normalization is still rather empirical. Bioinformatic algorithms that identify adequate normalization gene [31] or small nucleolar genes such as U6 [32] may be used for this purpose. Recent qRT-PCR array methods combine high sensitivity provided by the stem-loop qRT-PCR with the ability to analyze a larger number of miRNAs in a single experiment [28]. qRT-PCR has been widely used to perform miRNA expression profiling using several array platforms developed in recent years. This technology is less timeconsuming than others such as microarrays and NGS, and the results do not require processing by biostatisticians.

Yu et al. [33] investigated whether miRNA expression profiles were able to predict clinical outcome by analyzing 157 mature human miRNAs using a qRT-PCR array in fresh-frozen specimens from NSCLC patients. Cox regression analysis revealed a fivemiRNA signature that proved an independent predictor of cancer relapse and survival in both the testing set and an independent validation cohort. Another study analyzed differences in miRNA expression in bronchial carcinogenesis (four years duration). Sixty 
biopsies obtained by fluorescence bronchoscopy were examined by qRT-PCR Low Density Array (LDA), capable of detecting 365 miRNAs. The authors found that most miRNA expression levels evolved in two steps during the carcinogenesis process: i) decrease in earliest stages of carcinogenesis, and then ii) increased when malignant transformation was engaged at stage of severe dysplasia [34]. Using the same qRT-PCR array technology, Silva et al. [35] determined the vesicle-related miRNA expression profile obtained from plasma samples of 28 NSCLC patients and 20 healthy controls. NSCLC patients and healthy controls differed with respect to vesicle-related miRNAs in plasma. In addition, NSCLC patients with low levels of miR-30e-3p and those with high levels of let-7f had worse survival. A LDA Panel including 756 probes was used by Berghmans et al. [36] in a prospective study in NSCLC patients treated with cisplatin and vinorelbine in first line. They assessed the predictive and prognostic value of miRNAs in 38 bronchial biopsies obtained in treatment naïve patients. A miRNA signature composed of miR-149 and miR-375 was found to be predictive of response, whereas a score including four miRNAs (miR-200c, miR-424, miR-29c and miR-124) was able to stratify patients according to prognosis.

Hennessey et al. [37] examined expression of 180 miRNAs in serum of 30 treatment naïve NSCLC patients and 20 healthy controls by qRT-PCR assays (hydrolysis probe). They found that a combination of two differentially expressed miRNAs, miR-15b and miR-27b, was able to discriminate NSCLC patients from healthy controls with high sensitivity, specificity, positive predictive value (PPV) and negative predictive value (NPV) in the training and validation sets. However, the size of the analyzed cohorts was small and the findings require further validation. This year, Skrzypski et al. [38] have 
published a study using microfluidic cards with TaqMan probes in order to assess expression of 667 miRNAs in 50 squamous cell carcinoma (SCC) patients who underwent curative surgery. In these patients, miRNAs with highest predictive value for distant relapse were analyzed in an independent cohort composed by 134 FFPE samples from SCC patients and also in 89 samples from adenocarcinomas (ADC) and normal parenchyma. They identified and confirmed the prognostic role of three novel miRNAs (miR-662, miR-192 and miR-192*) in operable SCC.

Recently, Cazzoli et al. evaluated miRNAs isolated from plasma exosomes using a 724miRNA Ready-to-Use PCR Panel from Exiqon (Vedbaek, Denmark) [39]. MiRNAs were first assessed in a training set of 10 lung $A D C, 10$ lung granulomas and 10 healthy former smokers. Selected miRNAs were subsequently evaluated in a larger independent validation cohort (105 specimens: 50 lung adenocarcinomas, 30 lung granulomas, and 25 healthy smokers) by qRT-PCR. A four-miRNA signature (miR-378a, miR-379, miR-139-5p, and miR-200b-5p) was proposed to perform a screening test in lung cancer, and six miRNAs (miR-151a-5p, miR-30a-3p, miR-200b-5p, miR-629, miR100 , and miR-154-3p) were selected for the diagnostic test to determine lung ADC.

Microarrays and next generation sequencing (NGS) technologies are also used as screening tools because of their high throughput capacities (described below). However, results from these technologies need standardization and validation. qRTPCR has been widely used for this purpose, mainly due to its high sensitivity and specificity. For instance, Rosenfeld et al. [40] measured miRNA expression by microarray technology in 253 samples from different tumor tissues and metastases, developing a transparent classifier that differentiates tumors derived from different 
tissue origins and therefore, could be useful for tracing unknown primary sources. This classifier was successfully validated by qRT-PCR in 65 blinded samples. Boeri et al. [41] also validated their results using this approach in both tissue and plasma samples. They suggested that qRT-PCR assessment of miRNAs in plasma will be a potentially useful and clinically applicable procedure to improve lung cancer management. Similarly, the University of Maryland (Baltimore, USA) group discovered two sets of miRNAs which could be employed in early detection of ADC (miR-21, miR-486, miR-375 and miR200b) [42] and SCC (miR-205, miR-210 and miR-708) [43] in sputum. Furthermore, they extended their research to plasma samples, where miRNAs were stably present and reliably measured. The authors were able to distinguish NSCLC patients from healthy controls with $86 \%$ sensitivity and $97 \%$ specificity [44]; however, it should be mentioned that the number of samples analyzed in these studies was small.

A series of studies have analyzed expression of specific miRNAs selected for their potential function or predicted targets. In 2009, Gallardo et al. [14] reported the expression of miR-34 family members assessed in 70 NSCLC patients. They observed that miR-34 family members were downregulated in tumoral compared with normal tissue, and low levels of miR-34a expression correlated with high probability of relapse. They recently reported expression of miR-302-367cluster and miR-145, both related to transcription factors SRY-related HMG box 2 (SOX2) and octamer-binding transcription factor 4 (OCT4), in NSCLC patients. The group concluded that both miR-367 and miR145 are useful prognostic markers that may be used for risk stratification and selection of early NSCLC patients for adjuvant treatment [45]. Zhu et al. [46] analyzed gene expression levels of miR-183 family members, located on human chromosome 7 and 
previously identified as potential oncogenes in several tumor types. The study was performed in 70 paired lung cancer samples (primary cancer, non-cancerous tissues and serum), as well as 44 serum samples from healthy volunteers and lung cancer cell lines. They demonstrated that high expression of tumor and serum miRNAs of the miR183 family were associated with overall poor survival in lung cancer patients.

Similarly, Duncavage et al. [47] determined expression of six miRNAs (let-7a, miR-7, miR-21, miR-155, miR-210, and miR-221) with respect to recurrence in 46 surgically resected stage I NSCLC patients. Using FFPE tissue from both tumor and matched normal lung, they observed that down-regulation of miR-221 strongly correlated with recurrence in NSCLC. More recently, Chen et al. [48] analyzed expression of miRNA-17$5 p$ in 20 paired samples (lung cancer and adjacent normal tissues), and sera from 221 lung cancer patients and 54 matched controls. They reported that miR-17-5p overexpression in serum correlated with reduced survival and may be an independent prognostic factor. In another recently published article, Zhang et al. [49] assessed expression of 20 miRNAs by qRT-PCR in plasma samples from 105 female ADC patients, observing that circulating levels of miR-195 and miR-122 are associated with prognosis and EGFR mutation status. Association between miRNAs and EGFR has previously been explored, especially the role of miRNAs in tyrosine kinase inhibitor-resistant NSCLCs. Garofalo et al. [50] found that miR-30b/c and miR-221/2 control the expression of genes involved in the apoptotic response and thus in sensitivity to gefitinib. Moreover, Romano et al. [51] reported that miR-494 induced down-regulation of BIM which is an important apoptosis regulator involved in drug resistance in NSCLC. Therefore, the 
modulation of specific miRNAs may provide an approach to treatment of these patients.

\subsubsection{Microarray Platforms}

Microarrays platforms were among the first methods used in order to detect and quantify miRNAs. This technology, which allows the analysis of thousands of miRNAs in a single experiment, is based on the use of glass, quartz or nylon support platforms in which multiple probes are spotted or synthesized by photochemical synthesis $[52,53]$. Several aspects such as the short length of miRNAs, the existence of both mature miRNAs and their precursors, and melting temperature $(\mathrm{Tm})$ differences, due to the variance in GC content, should be taken into consideration when performing miRNA microarrays $[54,21]$. To overcome these pitfalls, higher sensitivity and affinity probes have been developed. For example, locked nucleic acid (LNA) capture probes, which are able to increase the thermal stability of the duplex [55], or probes with 5 '-endhairpin structure capable of avoiding hybridization to miRNA precursors [56].

Detection of miRNAs is usually performed using direct labelling with enzymatic reactions. For instance, T4 RNA ligase is widely used for the attachment of fluorophore-labeled nucleotides to mature miRNAs [56]. Microarray data must be normalized in order to eliminate background noise of the reaction and differences in the hybridization process which can be resolved using synthetic sRNAs or small nuclear ribonucleoproteins (snRNA) as a reference [57]. Furthermore, it is also important to validate the results obtained from microarrays with other technologies such as qPCR [21]. 
During the last decade, several studies using miRNA microarray have helped to elucidate the role of miRNAs in cancer-related processes. Moreover, some of these studies have been able to identify patterns which distinguish cancer patients from healthy controls, or classify patients according to clinical features and/or outcome. Volinia et al. [58] performed detailed large-scale miRNA profiles in 540 samples from six different cancer types, including lung, breast, stomach, prostate, colon, and pancreatic tumors. They identified a large portion of overexpressed miRNAs, some of which such as miR-17-5p, miR-20a, miR-21, miR-92, miR-106a, and miR-155, were already known to be associated with cancer

In lung cancer, Yanaihara et al. [59] identified a unique profile which allowed the discrimination of lung carcinomas from normal lung tissues as well as distinguishing between different histology subtypes in a cohort of 104 patients. Among the different miRNAs composing the profile, high hsa-miR-155 expression significantly correlated with survival in lung ADC. The results were further validated by hybridization and $\mathrm{QPCR}$ in the same samples and also in an independent set of patients with ADC histology. In a cohort of 61 SCC samples, Raponi et al. [23] identified 15 miRNAs that were differentially expressed between normal lung tissue and SC; some of these miRNAs were found to have prognostic value, among them miR-155 and let- 7 which were previously reported to be associated with poor prognosis in ADCs [59]. After performing a 752-miRNA microarray using specific and sensitive LNA probes, in 2010 Patnaik et al. presented the widest analysis of lung cancer miRNAs until then. In FFPE samples from 77 stage I NSCLC patients, several miRNAs showed contrasting expressions between cases with and without recurrence [60]. More recently, the same 
group reported differences in expression of 96 miRNAs in whole blood samples between ADCs and controls [61]. However, these results have not been independently validated thus far.

In tissue and plasma samples from a spiral-CT lung cancer screening trial, Boeri et al. [41] found miRNA signatures which significantly distinguished tumors from normal tissues, tumor histology, growth rate, and clinical outcome. Furthermore, miRNA expression analyses in different groups of plasma samples (collected 1-2 years prior to disease onset, at the time of CT detection, and in disease-free smokers enrolled in the screening trial) resulted in miRNA signatures with strong predictive, diagnostic and prognostic potential. The authors emphasized the potential usefulness of detection in plasma in clinical practice due to the non-invasiveness of the technique. Using serum instead of plasma, Roth et al. [62] carried out blood-based microarray profiling of 1158 different miRNAs using a microfluidic biochip in 21 NSCLC patients and 11 healthy individuals. In this work, they suggest that miR-361-3p and miR-625* might have a protective influence on the development of NSCLC, and therefore could be used as diagnostic tools.

\subsubsection{Next Generation Sequencing (NGS)}

Capillary electrophoresis (CE)-based Sanger sequencing, also known as "firstgeneration sequencing", has allowed scientists to study the genetic information of any biological system, including the human genome sequence. However, the limitations in throughput, scalability, speed, and resolution of this technology have led to the development of new sequencing methods, known as Next-Generation Sequencing (NGS). This is a group of methods that rely on template preparation, sequencing and 
imaging, and thorough bioinformatic data analysis (reviewed by M. L. Metzker) [63]. This technology has several advantages such as identification and quantification of known miRNAs, as well as detection of novel miRNAs.

The breakthrough came in 2005 when one of the first works using the sequencing-bysynthesis method, developed by 454 Life Science, was published [64]. Since then, several NGS platforms have been developed; the most important of which are considered to be 454 (Roche Diagnostics, Basel, Switzerland), SOLiD (Life Technologies, Foster City, CA, USA) and Solexa (Illumina, San Diego, CA, USA). NGS techniques have been applied in miRNA studies in many species and they have become a powerful approach both for discovery and profiling of miRNAs. The NGS process starts with the construction of a cDNA-library of specific samples using PCR. In this step, platformspecific adapters are ligated to the DNA products. The adaptors can be fixed to a solid phase in which the PCR takes place, such as in the Solexa platform, or to beads for emulsion PCR, as in the 454 and SOLiD platforms. After sequencing, bioinformatic analyses of the sequence reads are needed in order to identify known and novel miRNAs and for quantification of a given miRNA relative to the total reads in the sample [63].

NGS technologies also provide precise identification of miRNA sequences, permitting us to distinguish between miRNAs that differ by a single nucleotide and isomiRs (variants of the same miRNA) of varying length. One of the main limitations of this technology is the high cost, although these are decreasing with the development of new platforms and the use of DNA-barcodes which permit multiplexing of several samples in a single run [65]. Disadvantages are the need for a relatively large amount 
of RNA and the complex bioinformatic analyses involved. Several attempts have been made to analyze the whole transcriptome sequence in lung cancer patients $[66,67,68]$. However, to date, few articles have been published analyzing miRNAs by NGS in lung cancer. In 2008, Chen et al. [69] studied the presence of miRNAs in serum and plasma of humans and animals employing a Solexa platform. They reported 63 miRNAs that were specifically detected in the serum of 11 lung cancer patients. Among these, miR25 and miR-123 were further validated by qRT-PCR in a set of 152 lung cancer patients and 75 healthy donors, although sensitivity and specificity of these assays were not reported.

Solexa sequencing was also used by Hu et al. [70] to assess the prognostic impact of miRNA expression in human serum of NSCLC patients. They further validated miRNAs detected in serum by qRT-PCR in both a training and independent testing set of samples. The levels of four miRNAs (miR-486, miR-30d, miR-1 and miR-499) were significantly correlated with overall survival. Keller et al. [71] used SOLiD transcriptome sequencing for analysis of miRNAs in peripheral blood of 10 lung cancer patients and 10 healthy controls. They developed a bioinformatic pipeline to generate miRNA profiles and detect novel miRNAs with prognostic and predictive information that could inform diagnosis. With this approach they detected 76 previously unknown miRNAs and 41 novel mature forms of known precursors, as well as 39 miRNAs significantly altered in cancer patients. Recently, a miRNA-sequencing (miRNA-Seq) study was conducted using SOLiD platform in ten fresh-frozen tumor samples from lung ADC patients [72]. The investigators found that miR-31 was up-regulated in patients with lymph node metastasis, compared with those without lymph node 
metastasis. They validated the results by qRT-PCR and in an external validation cohort of 233 lung ADC cases from The Cancer Genome Atlas (TCGA) dataset. Furthermore, they carried out in vitro functional assays which showed that miR-31 increases cell migration, invasion, and proliferation in an ERK1/2 signaling-dependent manner.

\subsection{Analysis performed at single cell-level}

\subsubsection{In situ hybridization}

In situ hybridization (ISH) is a technology based on the use of labeled probes for the detection of DNA and RNA directly in tissue samples which permits evaluation of expression in the different cells of the tumor microenvironment. There are two ways to visualize nucleic acids of interest in situ: fluorescent (FISH) and chromogenic (CISH) detection. Both use target-specific probes that hybridize with the sample, but the technology needed to visualize results is different for each method. While CISH permits to gain genetic information in the context of tissue morphology, FISH allows the possibility to assay multiple targets simultaneously and visualize them within a single specimen. This technology has been recently applied to the detection of miRNAs, due to the incorporation of LNA modified probes as has happened in other technologies such as qRT-PCR and microarrays. The miRNA probes can be obtained from Exiqon (Vedbaek, Denmark), which provides reporter nucleotides that form the basis of this technology. The most commonly used reporter nucleotides are biotin and digoxigenin, the latter being more suitable since it is not present in mammalian tissues and therefore avoids false positive results. These systems employ a conjugated alkalinephosphatase and the chromogen nitro blue tetrazolium (NBT) which, in the presence of 5-bromo-4-chloro-3-indolynitrolphosphate (BCIP), yields a purple-blue precipitate. 
For the counterstaining, nuclear fast red is commonly used because it stains nuclei and is sufficient for analyzing cytoplasmatic signals [73].

Two parameters are essential for the ISH process and must be accurately optimized: The extent of proteinase-K digestion (which depends on the concentration, incubation temperature and time) and the hybridization temperature which has been found to provide a fairly high signal-to-noise ratio at $30^{\circ} \mathrm{C}$ below the measured $\mathrm{Tm}$ [74]. As for other methodologies, negative and positive controls are pivotal. The negative control must be a sequence with no similarity to any human or mouse sequence, such as Scramble probes. U6 probes have been widely used as positive control for ISH itself. In addition, it would also be interesting to analyze expression of an abundant miRNA with cell-specific origin in order to control the methodology's performance. For instance, miR-126 could be an adequate option because it is expressed in endothelial cells which are present in several types of tissues [75].

The major strength of the ISH methodology is that miRNA expression can be assessed specifically according to cellular compartment. As miRNA expression may have diverging prognostic impacts dependent on whether they are expressed in tumor cells or tumor stromal cells, it is essential to be able to localize the expression according to cellular compartments. Due to its novelty, to date, few attempts have been made to detect and analyze miRNA in lung cancer patients by ISH. The first study in reporting use of ISH in lung cancer samples was published by Voortman et al. [76] in 2010. The aim of this work was to determine if a panel of biologically relevant miRNAs could be used as prognostic or predictive biomarkers in the International Adjuvant Cancer Trial (IALT), one of the largest randomized studies of adjuvant chemotherapy in resected 
NSCLC patients. For this purpose, they analyzed expression of seven miRNAs (miR-21, miR-29b, miR-34a/b/c, miR-155, and let-7) by qRT-PCR and ISH, the latter in selected cases. The results indicated that none of the seven miRNAs provided prognostic or predictive information about their cohort. The authors pointed out that the specimens, which were collected from a worldwide multicenter study, had not been gathered in accordance with standardized fixation and storage protocols. It seems that fixation and procurement variations affect the efficacy of ISH to a larger extent than miRNA isolation and qRT-PCR [77].

To date, most publications on ISH detecting miRNAs in lung cancer have been published by the group of Bremnes and colleagues from Norway $[78,79,80]$. In 2011, they presented the first large-scale study combining high-throughput tissuemicroarrays (TMA) and ISH to evaluate the prognostic impact of miR-155 expression, which has frequently been reported as up-regulated in malignant cells. They found that high miR-155 expression was an independent negative prognostic factor in ADC and an independent favorable prognostic factor in SCC patients with regional nodal metastasis [79]. They further explored the correlation between miR-155 and several well-known angiogenic markers, finding that FGF2 was significantly associated with this miRNA [80]. Using the same cohort, they also evaluated the ISH expression of miR126 and its co-expression with VEGF-A by immunohistochemistry (IHC). MiR-126 is a key positive regulator that promotes angiogenesis in response to angiogenic growth factors, such as vascular endothelial growth factor-A (VEGFA). The analysis revealed that miR-126 is a strong independent negative prognostic factor in NSCLC, and its prognostic impact appears related to histology and nodal status [78]. Recently, miR- 
210 expression was also assessed in cancer and stromal cells of NSCLC patients and an association with improved disease-specific survival was observed (DSS) [81].

\section{CONCLUSION}

Since a compelling body of evidence points to the direct involvement of miRNAs in carcinogenesis, several technologies have been developed with the aim of detecting and analyzing these molecules in different types of samples. Early on, the use of microarrays appeared as a great advanced to enhance the knowledge of the biological implications of miRNAs as well as opening the gate to new investigations regarding the possible use of miRNAs as biomarkers. Although microarray technology permits largescale studies, the comparability and accuracy of the derived data was not adequate and data validation was lacking. For this purpose, qRT-PCR has been widely used due to its high degree of accuracy. Moreover, new qRT-PCR arrays have been developed for large-scale miRNA profiling. One of the main limitations of both technologies is that only known miRNAs can be examined. NGS has solved this problem, and novel and known miRNAs can be identified in a single experiment. Although NGS is still an expensive method, current advances are leading towards new versions of the instruments which increase the analytical speed and lower the cost.

Finally, a new miRNA detection technology, in situ hybridization, has emerged as an interesting option, mainly as it provides information about the exact localization of miRNAs. With this method, miRNAs can be specifically located within the tumor cell itself or within tumor stromal cells. As we have mentioned, several studies have already been published using the technologies previously described. A large amount of data is available on the potential use of miRNAs as diagnostic, prognostic and 
predictive biomarkers. However, more studies are needed in order to validate, optimize and standardize procedures. This is pivotal for the future application of miRNAs as clinical tools for lung cancer diagnosis and management.

\section{FUTURE PRESPECTIVE}

It is expected that most relevant miRNAs, presumably miRNA-signatures, will be validated as diagnostic, prognostic and predictive biomarkers for clinical use in lung cancer patients in the near future. Since specificity and sensitivity will no longer be a problem, the aim will then be to improve technologies in terms of time and cost. In this regard, we expect that NGS platforms will become the gold standard for analyzing miRNAs since this technology is becoming faster and more affordable and yields a greater amount of data than other techniques. Furthermore, since the field of bioinformatics is also advancing rapidly, dealing with results obtained from NGS will become easier and more practical. However, in specific cases in which the location of miRNAs will need to be assessed, ISH will be probably remain the best approach; hopefully this technology will become better harmonized and standardized. In the future, it is also expected that tissue specimen collection will become more standardized, and importantly, liquid biopsies will emerge as powerful tools for the detection of distinct biological markers, including miRNAs. miRNAs detected in this type of biopsies are expected to provide a clearer picture of tumor evolution overtime and will address the problem of tumor heterogeneity. In summary, miRNA-profiling will become a potent tool in the near future for lung cancer diagnosis and prognosis, as well as interesting therapeutic targets. 


\section{EXECUTIVE SUMMARY}

\section{MiRNAs in lung cancer}

- miRNAs are pivotal to the lung carcinogenesis process and present adequate characteristics to become biomarkers.

- Several miRNA-signatures have been associated with diagnosis and prognosis in lung cancer using different methodologies.

\section{MiRNAs isolation and purification}

- It is pivotal to use an adequate RNA isolation method in order to obtain reliable miRNA-profiling results.

\section{MiRNA detection methods}

- Platforms based on microarray and qRT-PCR have been widely used in the last years in order to perform miRNA-profiling analysis.

- NGS is becoming an important tool for miRNA analysis since it can detect known miRNA whilst also permitting discovery of new ones.

- ISH permits identification of specific miRNAs and their exact location within the tumor microenvironment. 


\section{Acknowledgements}

This study was partially supported by a grant from Ministerio de Ciencia e Inovación de España (TRA09-0132), Beca Roche en Onco-Hematología 2009 and Red Temática de Investigación Cooperativa en Cáncer (RD12/0036/0025).

\section{Disclosure}

The authors declare no conflict of interest. 
Table 1. Summary of relevant studies analyzing miRNAs in lung cancer using different technologies.

\begin{tabular}{|c|c|c|c|c|c|c|c|}
\hline $\begin{array}{l}\text { Reference } \\
\text { Year }\end{array}$ & $\begin{array}{l}\text { Sample } \\
\text { type }\end{array}$ & $\begin{array}{l}\text { Histology } \\
\text { Stage }\end{array}$ & $\begin{array}{l}\text { miRNAs } \\
\text { analyzed }\end{array}$ & $\begin{array}{l}\text { Cancer } \\
\text { cases no. }\end{array}$ & $\begin{array}{l}\text { VS } \\
\text { cases no. }\end{array}$ & $\begin{array}{l}\text { miRNA } \\
\text { value }\end{array}$ & Findings \\
\hline \multicolumn{8}{|c|}{ qRT-PCR } \\
\hline $\begin{array}{l}\text { Yu [33] } \\
2008\end{array}$ & $\begin{array}{l}\text { Frozen } \\
\text { tissue }\end{array}$ & $\begin{array}{l}\text { NSCLC } \\
|-| I \mid\end{array}$ & 157 & $\begin{array}{l}56 \text { TS } \\
56 \text { TTS }\end{array}$ & $\begin{array}{l}\text { YES } \\
62\end{array}$ & Prognostic & $\begin{array}{l}\text { 5-miRNA signature } \\
\text { associated with OS }\end{array}$ \\
\hline $\begin{array}{l}\text { Silva [35] } \\
2011\end{array}$ & Plasma & $\begin{array}{l}\text { NSCLC } \\
\text { I-IV }\end{array}$ & 365 & $28 \mathrm{TS}$ & $\begin{array}{l}\text { YES } \\
78\end{array}$ & Prognostic & $\begin{array}{l}\text { miR-30e-3p and let-7f } \\
\text { associated with OS }\end{array}$ \\
\hline $\begin{array}{l}\text { Berghmans [36] } \\
2013\end{array}$ & $\begin{array}{l}\text { Bronchial } \\
\text { biopsies }\end{array}$ & $\begin{array}{l}\text { NSCLC } \\
\text { NR }\end{array}$ & 756 & 38 & NO & $\begin{array}{l}\text { Predictive } \\
\text { Prognostic }\end{array}$ & $\begin{array}{l}\text { 2-miRNAsignature } \\
\text { predictive of RS } \\
\text { 4-miRNA prognostic } \\
\text { score for OS }\end{array}$ \\
\hline $\begin{array}{l}\text { Hennessey [37] } \\
2012\end{array}$ & Serum & $\begin{array}{l}\text { NSCLC } \\
\text { I-IV }\end{array}$ & 180 & $\begin{array}{l}30 \text { TS } \\
55 \text { TTS }\end{array}$ & NO & Diagnostic & $\begin{array}{l}\text { miR-15b and miR-27b } \\
\text { discriminate NSCLC }\end{array}$ \\
\hline $\begin{array}{l}\text { Skrzypski [38] } \\
2014\end{array}$ & $\begin{array}{l}\text { Fresh } \\
\text { tissue } \\
\text { FFPE }\end{array}$ & $\begin{array}{l}\text { NSCLC } \\
\text { I-IIIA }\end{array}$ & 667 & $50 \mathrm{TS}$ & $\begin{array}{l}\text { YES } \\
134 \text { SCC } \\
89 \text { ADC }\end{array}$ & Prognostic & $\begin{array}{l}3 \text { miRNAs correlate } \\
\text { with relapse in SCC }\end{array}$ \\
\hline $\begin{array}{l}\text { Cazzoli [39] } \\
2013\end{array}$ & $\begin{array}{l}\text { Plasma } \\
\text { exosomes }\end{array}$ & $\begin{array}{l}\text { ADC } \\
1\end{array}$ & 724 & $10 T S$ & $\begin{array}{l}\text { YES } \\
50\end{array}$ & Diagnostic & $\begin{array}{l}\text { 6-miRNA signature } \\
\text { discriminates } A D C\end{array}$ \\
\hline $\begin{array}{l}\text { Yu [42] } \\
2010\end{array}$ & $\begin{array}{l}\text { Tissue } \\
\text { Sputum }\end{array}$ & $\begin{array}{l}\mathrm{ADC} \\
\mathrm{I}\end{array}$ & 377 & $\begin{array}{l}20 \text { DS } \\
36 \text { OPS }\end{array}$ & $\begin{array}{l}\text { YES } \\
64\end{array}$ & Diagnostic & $\begin{array}{l}\text { 4-miRNA signature } \\
\text { discriminates } A D C\end{array}$ \\
\hline $\begin{array}{l}\text { Gallardo [14] } \\
2009\end{array}$ & FFPE & $\begin{array}{l}\text { NSCLC } \\
\text { I-III }\end{array}$ & 3 & 70 & NO & Prognostic & $\begin{array}{l}\text { miR-34a correlates } \\
\text { with relapse }\end{array}$ \\
\hline $\begin{array}{l}\text { Duncavage [47] } \\
2010\end{array}$ & FFPE & $\begin{array}{l}\text { NSCLC } \\
\text { I }\end{array}$ & 6 & 46 & NO & Prognostic & $\begin{array}{l}\text { miR- } 221 \text { correlates } \\
\text { with relapse }\end{array}$ \\
\hline \multicolumn{8}{|c|}{ Microarray platforms } \\
\hline $\begin{array}{l}\text { Yanaihara [59] } \\
2006\end{array}$ & Tissue & $\begin{array}{l}\text { NSCLC } \\
\text { I-IV }\end{array}$ & 352 & $104 \mathrm{TS}$ & $\begin{array}{l}\text { YES } \\
32\end{array}$ & Prognostic & $\begin{array}{l}\text { miR-155 correlates } \\
\text { with OS }\end{array}$ \\
\hline $\begin{array}{l}\text { Raponi [23] } \\
2009\end{array}$ & $\begin{array}{l}\text { Frozen } \\
\text { tissue }\end{array}$ & $\begin{array}{l}\text { SCC } \\
\text { I-IIIB }\end{array}$ & 328 & 57 & NO & Prognostic & $\begin{array}{l}\text { miR-155 and miR- } 46 b \\
\text { correlate with OS }\end{array}$ \\
\hline $\begin{array}{l}\text { Patnaik [60] } \\
2010\end{array}$ & FFPE & $\begin{array}{l}\text { NSCLC } \\
1\end{array}$ & 752 & 77 & NO & Prognostic & $\begin{array}{l}\text { 6-miRNA signature } \\
\text { associated with OS }\end{array}$ \\
\hline
\end{tabular}




\begin{tabular}{|c|c|c|c|c|c|c|c|}
\hline $\begin{array}{l}\text { Boeri [41] } \\
2011\end{array}$ & $\begin{array}{l}\text { Frozen } \\
\text { tissue } \\
\text { Plasma }\end{array}$ & $\begin{array}{l}\text { Lung } \\
\text { cancer } \\
\text { I-IV }\end{array}$ & 235 & $\begin{array}{l}28 \mathrm{DS} \\
19 \mathrm{TS}\end{array}$ & $\begin{array}{l}\text { YES } \\
22\end{array}$ & $\begin{array}{l}\text { Diagnostic } \\
\text { Prognostic }\end{array}$ & $\begin{array}{l}\text { miRNA signatures } \\
\text { with diagnostic and } \\
\text { prognostic potential }\end{array}$ \\
\hline $\begin{array}{l}\text { Roth [62] } \\
2012\end{array}$ & Serum & $\begin{array}{l}\text { NSCLC } \\
\text { I-IV }\end{array}$ & 1158 & $21 \mathrm{TS}$ & $\begin{array}{l}\text { YES } \\
97\end{array}$ & Diagnostic & $\begin{array}{l}\text { Low miR-361-3p and } \\
\text { miR-625* discriminate } \\
\text { NSCLC }\end{array}$ \\
\hline
\end{tabular}

\section{Next Generation Sequencing}

\begin{tabular}{|c|c|c|c|c|c|c|c|}
\hline $\begin{array}{l}\mathrm{Hu}[70] \\
2010\end{array}$ & Serum & $\begin{array}{l}\text { SCC/ADC } \\
\text { I-IIIA }\end{array}$ & - & $\begin{array}{l}60 \text { TS I } \\
120 \text { TS II }\end{array}$ & $\begin{array}{l}\text { YES } \\
123\end{array}$ & Prognostic & $\begin{array}{l}\text { 4-miRNA signature } \\
\text { associated with OS }\end{array}$ \\
\hline
\end{tabular}

\begin{tabular}{|c|c|c|c|c|c|c|c|}
\hline $\begin{array}{l}\text { Voortman [76] } \\
2010\end{array}$ & FFPE & $\begin{array}{l}\text { NSCLC } \\
\text { I-III }\end{array}$ & 7 & 639 & NO & No value & $\begin{array}{l}7 \text { miRNAs were } \\
\text { neither prognostic nor } \\
\text { predictive }\end{array}$ \\
\hline $\begin{array}{l}\text { Donnem }[79,78] \\
2011\end{array}$ & FFPE & $\begin{array}{l}\text { NSCLC } \\
\text { I-IIIA }\end{array}$ & 1 & 335 & NO & Prognostic & $\begin{array}{l}\text { miR-126 is a negative } \\
\text { prognostic factor } \\
\text { miR-155 is a positive } \\
\text { prognostic factor in } \\
\text { SCC }\end{array}$ \\
\hline
\end{tabular}

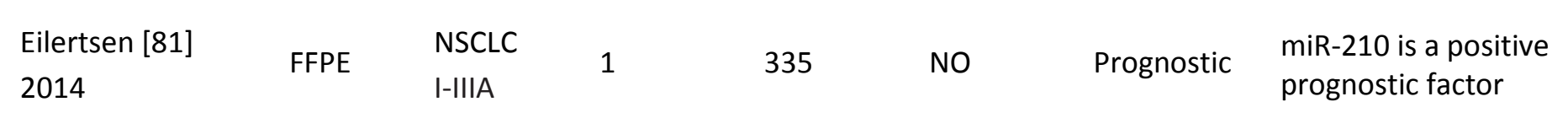

ADC: Adenocarcinoma; DS: Discovery set; FFPE: Formalin-fixed, paraffin-embedded; ISH: In situ hybridization; NR: Not reported; NSCLC: Non-small cell lung cancer; OPS: Optimization set; OS: Overall survival; qRT-PCR: Quantitative reverse transcriptase PCR; RS: Response; SCC: Squamous cell carcinoma; TTS: Test set; TS: Training set; VS: Validation set. 
Table 2. Available technologies for study of microRNAs.

\begin{tabular}{|c|c|c|c|c|}
\hline Methodology & Main characteristics & Advantages & Disadvantages & Companies \\
\hline qRT-PCR & $\begin{array}{l}\text { Gold standard for } \\
\text { gene expression } \\
\text { quantification } \\
\text { For miRNA analysis, } \\
\text { RNA has to be } \\
\text { converted into cDNA } \\
\text { Detection and } \\
\text { quantification of } \\
\text { miRNAs by } \\
\text { fluorescence }\end{array}$ & $\begin{array}{l}\text { High sensitivity and } \\
\text { specificity } \\
\text { Requires a low } \\
\text { input of RNA } \\
\text { Less time- } \\
\text { consuming } \\
\text { Do not require } \\
\text { biostatistics. } \\
\text { High accuracy }\end{array}$ & $\begin{array}{l}\text { No identification } \\
\text { of novel miRNAs } \\
\text { Medium } \\
\text { throughput } \\
\text { Lack of good } \\
\text { normalization } \\
\text { genes }\end{array}$ & $\begin{array}{l}\text { Life } \\
\text { Technologies } \\
\text { Exiqon } \\
\text { Qiagen }\end{array}$ \\
\hline $\begin{array}{l}\text { MiRNA } \\
\text { microarrays }\end{array}$ & $\begin{array}{l}\text { Based on hybridization } \\
\text { between target } \\
\text { molecules and their } \\
\text { complementary probes } \\
\text { Allows detection and } \\
\text { quantification of } \\
\text { miRNAs } \\
\text { Support platforms with } \\
\text { multiple probes } \\
\text { spotted }\end{array}$ & $\begin{array}{l}\text { Established } \\
\text { method } \\
\text { Affordable } \\
\text { Analysis of } \\
\text { thousands of } \\
\text { miRNAs and } \\
\text { samples in a run }\end{array}$ & $\begin{array}{l}\text { Low specificity } \\
\text { compared to } \\
\text { other methods } \\
\text { Low accuracy } \\
\text { No identification } \\
\text { of novel miRNAs }\end{array}$ & $\begin{array}{l}\text { Life } \\
\text { Technologies } \\
\text { Affymetrix } \\
\text { Agilent } \\
\text { Exiqon }\end{array}$ \\
\hline $\begin{array}{l}\text { Next } \\
\text { Generation } \\
\text { Sequencing }\end{array}$ & $\begin{array}{l}\text { Template preparation, } \\
\text { sequencing and } \\
\text { imaging } \\
\text { Different platforms } \\
\text { available } \\
\text { Detection, } \\
\text { quantification and new } \\
\text { identification of } \\
\text { miRNAs }\end{array}$ & $\begin{array}{l}\text { Identification of } \\
\text { known and novel } \\
\text { miRNAs } \\
\text { Identification } \\
\text { between variants } \\
\text { of the same miRNA } \\
\text { High throughput }\end{array}$ & $\begin{array}{l}\text { Requires a high } \\
\text { input of RNA } \\
\text { Requires } \\
\text { complicated } \\
\text { bioinformatic } \\
\text { analyses } \\
\text { Relatively } \\
\text { expensive }\end{array}$ & $\begin{array}{l}\text { Life } \\
\text { Technologies } \\
\text { Illumina } \\
\text { Roche }\end{array}$ \\
\hline $\begin{array}{l}\text { In situ } \\
\text { hybridization }\end{array}$ & $\begin{array}{l}\text { Use of probes labeled } \\
\text { with LNA } \\
\text { Detection, semi- } \\
\text { quantification and } \\
\text { localization of the } \\
\text { miRNAs }\end{array}$ & $\begin{array}{l}\text { Assess exact } \\
\text { localization of } \\
\text { miRNAs within } \\
\text { tissue and cells } \\
\text { Does not require } \\
\text { biostatistics }\end{array}$ & $\begin{array}{l}\text { Requires } \\
\text { accurate } \\
\text { optimization } \\
\text { No identification } \\
\text { of novel miRNAs }\end{array}$ & Exiqon \\
\hline
\end{tabular}

CDNA: Complementary DNA; qRT-PCR: Quantitative reverse transcriptase PCR; LNA: Locked nucleic acid

Affymetrix (Santa Clara, CA, USA); Agilent Technologies (Santa Clara, CA, USA); Exiqon (Vedbaek, Denmark); Illumina (San Diego, CA, USA); Life Technologies (Foster City, CA, USA); Qiagen (Hilden, Germany); Roche Diagnostics (Basel, Switzerland). 
Table 3. Summary of most relevant miRNAs in lung cancer and their clinical implications.

\begin{tabular}{|c|c|c|c|}
\hline miRNA & $\begin{array}{l}\text { Expression in } \\
\text { lung cancer }\end{array}$ & Clinical correlation & References \\
\hline miR-126 & $\downarrow$ & $\begin{array}{l}\text { Distinguish between NSCLC patients and } \\
\text { healthy controls and it is an independent } \\
\text { negative prognostic factor }\end{array}$ & {$[41,42,43,44,59,78]$} \\
\hline let-7 & $\downarrow$ & $\begin{array}{l}\text { Distinguish between NSCLC patients and } \\
\text { healthy controls and it is associated with } \\
\text { shortened survival }\end{array}$ & {$[12,23,35,47,59]$} \\
\hline $\operatorname{miR}-21$ & $\uparrow$ & $\begin{array}{l}\text { Distinguish between NSCLC or ADC patients } \\
\text { and healthy controls }\end{array}$ & {$[41,42,44,58,59]$} \\
\hline miR-210 & $\uparrow$ & $\begin{array}{l}\text { Distinguish between SCC and healthy controls } \\
\text { and it is associated with improved disease- } \\
\text { specific survival }\end{array}$ & {$[23,41,43,59,81]$} \\
\hline miR-155 & $\uparrow$ & $\begin{array}{l}\text { Distinguish between NSCLC patients and } \\
\text { healthy controls and it is associated with OS }\end{array}$ & {$[23,58,59,79]$} \\
\hline miR-221 & $\uparrow$ & $\begin{array}{l}\text { Associated with aggressive NSCLC, with } \\
\text { patients relapse and with resistance to TKIs }\end{array}$ & {$[13,47,50]$} \\
\hline miR-205 & $\uparrow$ & $\begin{array}{l}\text { Distinguish between NSCLC or SCC patients } \\
\text { and healthy controls }\end{array}$ & {$[43,59,69]$} \\
\hline miR-145 & $\downarrow$ & $\begin{array}{l}\text { Associated with unfavourable prognosis in } \\
\text { NSCLC }\end{array}$ & {$[42,45,59]$} \\
\hline miR-34 & $\downarrow$ & $\begin{array}{l}\text { Distinguish between SCC and healthy controls } \\
\text { and it is associated with proliferation and } \\
\text { relapse }\end{array}$ & {$[11,14]$} \\
\hline miR-31 & $\uparrow$ & $\begin{array}{l}\text { Associated with ADC patients with lymph } \\
\text { node metastasis }\end{array}$ & [72] \\
\hline
\end{tabular}

ADC: Adenocarcinoma; NSCLC: Non-small cell lung cancer; OS: Overall survival; SCC: Squamous cell carcinoma; TKIs: Tyrosine kinase inhibitors; $\uparrow$ Increased; $\downarrow$ Decreased 


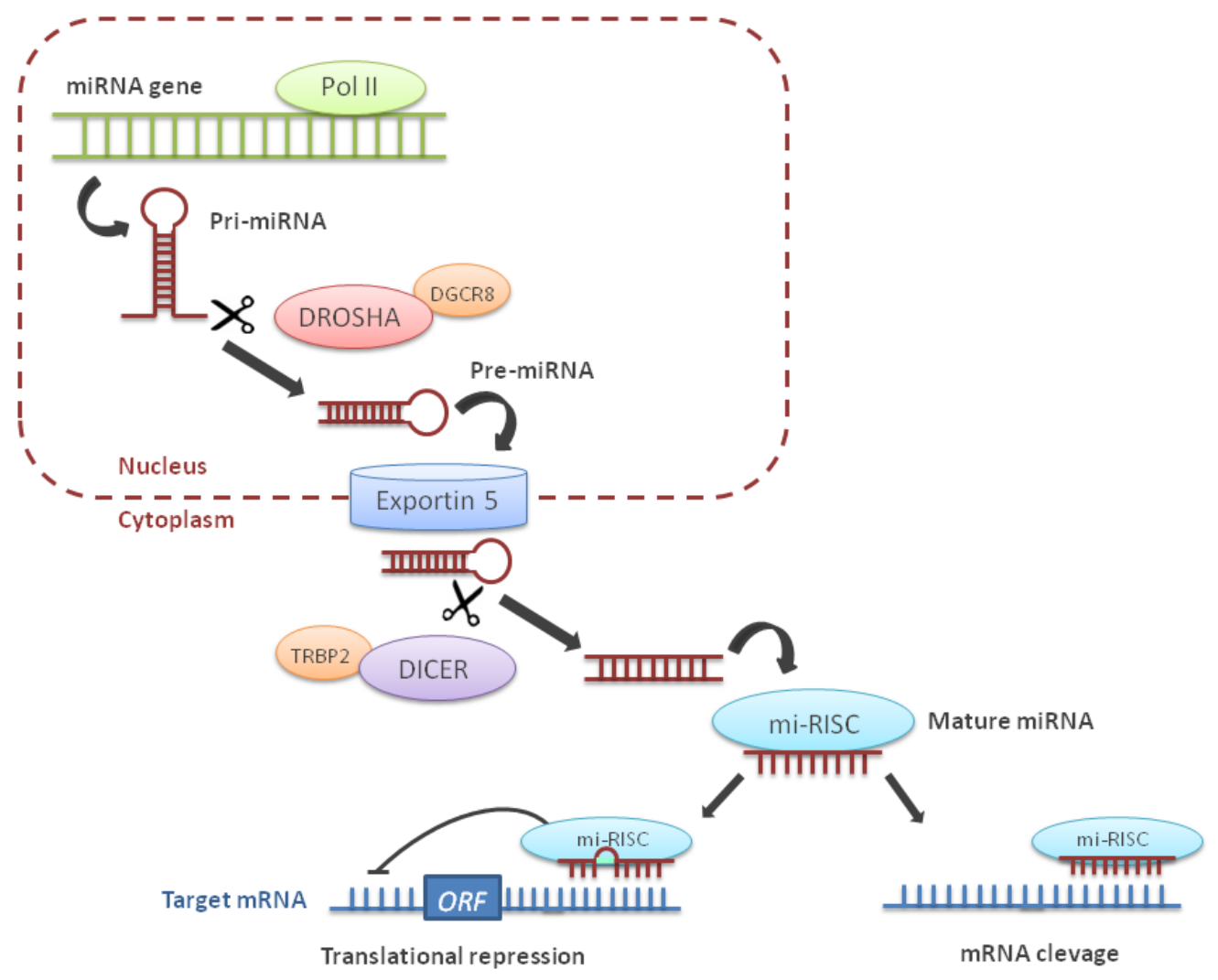

Figure 1. MicroRNA (miRNA) biogenesis and mechanisms of action. In the nucleus, miRNA genes are transcribed by RNA Pol II into a long pri-miRNA transcript. Pri-miRNA is then processed by a complex that includes RNase III enzyme Drosha to form premiRNA. This precursor is exported into the cytoplasm by Exportin 5, where it is further processed by DICER. A double-stranded miRNA of approximately 20 nucleotides is released and unwound by an helicase [6]. Mature miRNA is incorporated into the miRISC complex, which binds to complementary sites in the mRNA target. Perfect complementarity of the binding leads to the cleavage of the target mRNA, whereas imperfect complementarity results in repression of the translational process [82]. 
DGCR8: DiGeorge syndrome critical region gene 8; mi-RISC: miRNA-associated multiprotein RNA-induced silencing complex; ORF: Open reading frame; Pol II: Polymerase II; TRBP2: Trans-Activation-Responsive RNA-Binding Protein 2. 


\section{BIBLIOGRAPHY}

1. Jemal A, Bray F, Center MM, Ferlay J, Ward E, Forman D. Global cancer statistics. CA Cancer J.Clin. 61(2), 69-90 (2011).

2. Herbst RS, Heymach JV, Lippman SM. Lung cancer. N.Engl.J.Med. 359(13), 13671380 (2008).

3. Ferlay J, Parkin DM, Steliarova-Foucher E. Estimates of cancer incidence and mortality in Europe in 2008. Eur.J.Cancer 46(4), 765-781 (2010).

4. Goldstraw P, Crowley J, Chansky K et al. The IASLC Lung Cancer Staging Project: proposals for the revision of the TNM stage groupings in the forthcoming (seventh) edition of the TNM Classification of malignant tumours. J.Thorac.Oncol. 2(8), 706-714 (2007).

5. Lee RC, Feinbaum RL, Ambros V. The C. elegans heterochronic gene lin-4 encodes small RNAs with antisense complementarity to lin-14. Cell 75(5), 843854 (1993).

6. Winter J, Jung S, Keller S, Gregory RI, Diederichs S. Many roads to maturity: microRNA biogenesis pathways and their regulation. Nat.Cell Biol. 11(3), 228234 (2009).

7. Lai EC. Micro RNAs are complementary to 3' UTR sequence motifs that mediate negative post-transcriptional regulation. Nat.Genet. 30(4), 363-364 (2002).

8. Stark A, Brennecke J, Bushati N, Russell RB, Cohen SM. Animal MicroRNAs confer robustness to gene expression and have a significant impact on 3'UTR evolution. Cell 123(6), 1133-1146 (2005).

9. Zhang $B$, Pan X, Cobb GP, Anderson TA. microRNAs as oncogenes and tumor suppressors. Dev.Biol. 302(1), 1-12 (2007). 
10. Calin GA, Dumitru CD, Shimizu M et al. Frequent deletions and down-regulation of micro- RNA genes miR15 and miR16 at 13q14 in chronic lymphocytic leukemia. Proc NatI.Acad.Sci.U.S.A 99(24), 15524-15529 (2002).

\section{**First report to described miRNAs involved in the carcinogenesis of chronic lymphocytic leukaemia.}

11. Landi MT, Zhao $\mathrm{Y}$, Rotunno $\mathrm{M}$ et al. MicroRNA expression differentiates histology and predicts survival of lung cancer. Clin.Cancer Res. 16(2), 430-441 (2010).

12. Takamizawa J, Konishi $\mathrm{H}$, Yanagisawa $\mathrm{K}$ et al. Reduced expression of the let-7 microRNAs in human lung cancers in association with shortened postoperative survival. Cancer Res. 64(11), 3753-3756 (2004).

\section{*One of the first studies to analyze the use of miRNAs as prognostic biomarkers in NSCLC.}

13. Garofalo M, Di LG, Romano G et al. miR-221\&222 regulate TRAIL resistance and enhance tumorigenicity through PTEN and TIMP3 downregulation. Cancer Cell 16(6), 498-509 (2009).

14. Gallardo E, Navarro A, Vinolas $\mathrm{N}$ et al. miR-34a as a prognostic marker of relapse in surgically resected non-small-cell lung cancer. Carcinogenesis 30(11), 1903-1909 (2009).

15. Lu J, Getz G, Miska EA et al. MicroRNA expression profiles classify human cancers. Nature 435(7043), 834-838 (2005).

16. Xi Y, Nakajima G, Gavin E et al. Systematic analysis of microRNA expression of RNA extracted from fresh frozen and formalin-fixed paraffin-embedded samples. RNA. 13(10), 1668-1674 (2007).

17. Shen J, Jiang F. Applications of MicroRNAs in the Diagnosis and Prognosis of Lung Cancer. Expert.Opin.Med.Diagn. 6(3), 197-207 (2012). 
18. Doleshal M, Magotra AA, Choudhury B, Cannon BD, Labourier E, Szafranska AE. Evaluation and validation of total RNA extraction methods for microRNA expression analyses in formalin-fixed, paraffin-embedded tissues. J.Mol.Diagn. 10(3), 203-211 (2008).

19. Taylor DD , Gercel-Taylor C. MicroRNA signatures of tumor-derived exosomes as diagnostic biomarkers of ovarian cancer. Gynecol.Oncol 110(1), 13-21 (2008).

20. Ibberson D, Benes V, Muckenthaler MU, Castoldi M. RNA degradation compromises the reliability of microRNA expression profiling. BMC.Biotechnol. 9, 102 (2009).

21. Yin JQ, Zhao RC, Morris KV. Profiling microRNA expression with microarrays. Trends Biotechnol. 26(2), 70-76 (2008).

22. Beuvink I, Kolb FA, Budach $W$ et al. A novel microarray approach reveals new tissue-specific signatures of known and predicted mammalian microRNAs. Nucleic Acids Res. 35(7), e52 (2007).

23. Raponi M, Dossey L, Jatkoe T et al. MicroRNA classifiers for predicting prognosis of squamous cell lung cancer. Cancer Res. 69(14), 5776-5783 (2009).

24. Benes V, Castoldi M. Expression profiling of microRNA using real-time quantitative PCR, how to use it and what is available. Methods 50(4), 244-249 (2010).

25. Dijkstra JR, Mekenkamp $\amalg$, Teerenstra S, de K, I, Nagtegaal ID. MicroRNA expression in formalin-fixed paraffin embedded tissue using real time quantitative PCR: the strengths and pitfalls. J.Cell Mol.Med. 16(4), 683-690 (2012).

26. Chen C, Ridzon DA, Broomer AJ et al. Real-time quantification of microRNAs by stem-loop RT-PCR. Nucleic Acids Res. 33(20), e179 (2005). 
27. Lao K, Xu NL, Yeung V, Chen C, Livak KJ, Straus NA. Multiplexing RT-PCR for the detection of multiple miRNA species in small samples. Biochem.Biophys.Res.Commun. 343(1), 85-89 (2006).

28. Mestdagh $\mathrm{P}$, Feys $\mathrm{T}$, Bernard $\mathrm{N}$ et al. High-throughput stem-loop RT-qPCR miRNA expression profiling using minute amounts of input RNA. Nucleic Acids Res. 36(21), e143 (2008).

29. Nolan T, Hands RE, Bustin SA. Quantification of mRNA using real-time RT-PCR. Nat.Protoc. 1(3), 1559-1582 (2006).

30. Zipper $\mathrm{H}$, Brunner $\mathrm{H}$, Bernhagen J, Vitzthum F. Investigations on DNA intercalation and surface binding by SYBR Green I, its structure determination and methodological implications. Nucleic Acids Res. 32(12), e103 (2004).

31. Mohammadian A, Mowla SJ, Elahi E, Tavallaei M, Nourani MR, Liang Y. Normalization of miRNA qPCR high-throughput data: a comparison of methods. Biotechno.Lett. 35(6), 843-851 (2013).

32. Xie $\mathrm{Y}$, Todd NW, Liu Z et al. Altered miRNA expression in sputum for diagnosis of non-small cell lung cancer. Lung Cancer 67(2), 170-176 (2010).

33. Yu SL, Chen HY, Chang GC et al. MicroRNA signature predicts survival and relapse in lung cancer. Cancer Cell 13(1), 48-57 (2008).

34. Mascaux C, Laes JF, Anthoine $G$ et al. Evolution of microRNA expression during human bronchial squamous carcinogenesis. Eur.Respir.J. 33(2), 352-359 (2009).

* First study to show that miRNAs are involved in the different steps of bronchial carcinogenesis process.

35. Silva J, Garcia V, Zaballos A et al. Vesicle-related microRNAs in plasma of nonsmall cell lung cancer patients and correlation with survival. Eur.Respir.J. 37(3), 617-623 (2011). 
36. Berghmans $T$, Ameye L, Willems $L$ et al. Identification of microRNA-based signatures for response and survival for non-small cell lung cancer treated with cisplatin-vinorelbine A ELCWP prospective study. Lung Cancer 82(2), 340-345 (2013).

37. Hennessey PT, Sanford T, Choudhary A et al. Serum microRNA biomarkers for detection of non-small cell lung cancer. PLoS.One. 7(2), e32307 (2012).

38. Skrzypski M, Czapiewski P, Goryca K et al. Prognostic value of miRNA expression in operable non-small cell lung cancer patients. Br.J.Cancer 110(4), 991-1000 (2014).

39. Cazzoli R, Buttitta F, Di NM et al. microRNAs derived from circulating exosomes as noninvasive biomarkers for screening and diagnosing lung cancer. J.Thorac.Oncol 8(9), 1156-1162 (2013).

40. Rosenfeld N, Aharonov R, Meiri E et al. MicroRNAs accurately identify cancer tissue origin. Nat.Biotechnol. 26(4), 462-469 (2008).

41. Boeri $M$, Verri $C$, Conte $D$ et al. MicroRNA signatures in tissues and plasma predict development and prognosis of computed tomography detected lung cancer. Proc NatI.Acad.Sci.U.S.A 108(9), 3713-3718 (2011).

\section{** Pointed out the role of miRNAs present in tissue and plasma as molecular predictors of lung cancer.}

42. Yu L, Todd NW, Xing L et al. Early detection of lung adenocarcinoma in sputum by a panel of microRNA markers. Int.J.Cancer 127(12), 2870-2878 (2010).

43. Xing L, Todd NW, Yu L, Fang H, Jiang F. Early detection of squamous cell lung cancer in sputum by a panel of microRNA markers. Mod.Pathol. 23(8), 11571164 (2010).

44. Shen J, Todd NW, Zhang $\mathrm{H}$ et al. Plasma microRNAs as potential biomarkers for non-small-cell lung cancer. Lab Invest 91(4), 579-587 (2011). 
45. Campayo $\mathrm{M}$, Navarro $\mathrm{A}$, Vinolas $\mathrm{N}$ et al. Low miR-145 and high miR-367 are associated with unfavourable prognosis in resected nonsmall cell lung cancer. Eur.Respir.J. 41(5), 1172-1178 (2013).

46. Zhu W, Liu X, He J, Chen D, Hunag Y, Zhang YK. Overexpression of members of the microRNA-183 family is a risk factor for lung cancer: a case control study. BMC.Cancer 11, 393 (2011).

47. Duncavage E, Goodgame B, Sezhiyan A, Govindan R, Pfeifer J. Use of microRNA expression levels to predict outcomes in resected stage I non-small cell lung cancer. J.Thorac.Oncol 5(11), 1755-1763 (2010).

48. Chen $Q$, Si $Q$, Xiao $S$ et al. Prognostic significance of serum miR-17-5p in lung cancer. Med.Oncol 30(1), 353 (2013).

49. Zhang H, Su Y, Xu F, Kong J, Yu H, Qian B. Circulating MicroRNAs in Relation to EGFR Status and Survival of Lung Adenocarcinoma in Female Non-Smokers. PLoS.One. 8(11), e81408 (2013).

50. Garofalo M, Romano G, Di LG et al. EGFR and MET receptor tyrosine kinasealtered microRNA expression induces tumorigenesis and gefitinib resistance in lung cancers. Nat.Med. 18(1), 74-82 (2012).

51. Romano G, Acunzo M, Garofalo $M$ et al. MiR-494 is regulated by ERK1/2 and modulates TRAIL-induced apoptosis in non-small-cell lung cancer through BIM down-regulation. Proc NatI.Acad.Sci.U.S.A 109(41), 16570-16575 (2012).

52. Kreil DP, Russell RR, Russell S. Microarray oligonucleotide probes. Methods Enzymol. 410, 73-98 (2006).

53. Krichevsky AM, King KS, Donahue CP, Khrapko K, Kosik KS. A microRNA array reveals extensive regulation of microRNAs during brain development. RNA. 9(10), 1274-1281 (2003). 
54. Shingara J, Keiger K, Shelton J et al. An optimized isolation and labeling platform for accurate microRNA expression profiling. RNA. 11(9), 1461-1470 (2005).

55. Castoldi $M$, Schmidt S, Benes $V$ et al. A sensitive array for microRNA expression profiling (miChip) based on locked nucleic acids (LNA). RNA. 12(5), 913-920 (2006).

56. Wang $H$, Ach RA, Curry B. Direct and sensitive miRNA profiling from low-input total RNA. RNA. 13(1), 151-159 (2007).

57. Davison TS, Johnson CD, Andruss BF. Analyzing micro-RNA expression using microarrays. Methods Enzymol. 411, 14-34 (2006).

58. Volinia S, Calin GA, Liu CG et al. A microRNA expression signature of human solid tumors defines cancer gene targets. Proc Natl.Acad.Sci.U.S.A 103(7), 22572261 (2006).

* Describes miRNA deregulation in cancer patients with respect to the normal tissue counterpart in different types of tumors, including lung cancer.

59. Yanaihara N, Caplen N, Bowman E et al. Unique microRNA molecular profiles in lung cancer diagnosis and prognosis. Cancer Cell 9(3), 189-198 (2006).

60. Patnaik SK, Kannisto E, Knudsen S, Yendamuri S. Evaluation of microRNA expression profiles that may predict recurrence of localized stage I non-small cell lung cancer after surgical resection. Cancer Res. 70(1), 36-45 (2010).

61. Patnaik SK, Yendamuri S, Kannisto E, Kucharczuk JC, Singhal S, Vachani A. MicroRNA expression profiles of whole blood in lung adenocarcinoma. PLoS.One. 7(9), e46045 (2012).

62. Roth C, Stuckrath I, Pantel K, Izbicki JR, Tachezy M, Schwarzenbach H. Low levels of cell-free circulating miR-361-3p and miR-625* as blood-based markers for discriminating malignant from benign lung tumors. PLoS.One. 7(6), e38248 (2012). 
63. Metzker ML. Sequencing technologies - the next generation. Nat.Rev.Genet. 11(1), 31-46 (2010).

64. Margulies $M$, Egholm $M$, Altman WE et al. Genome sequencing in microfabricated high-density picolitre reactors. Nature 437(7057), 376-380 (2005).

65. Pritchard CC, Cheng HH, Tewari M. MicroRNA profiling: approaches and considerations. Nat.Rev.Genet. 13(5), 358-369 (2012).

66. Beane J, Vick J, Schembri F et al. Characterizing the impact of smoking and lung cancer on the airway transcriptome using RNA-Seq. Cancer Prev. Res.(Phila) 4(6), 803-817 (2011).

67. Kalari KR, Rossell D, Necela BM et al. Deep Sequence Analysis of Non-Small Cell Lung Cancer. Integrated Analysis of Gene Expression, Alternative Splicing, and Single Nucleotide Variations in Lung Adenocarcinomas with and without Oncogenic KRAS Mutations. Front Oncol 2, 12 (2012).

68. Ju YS, Lee WC, Shin JY et al. A transforming KIF5B and RET gene fusion in lung adenocarcinoma revealed from whole-genome and transcriptome sequencing. Genome Res. 22(3), 436-445 (2012).

69. Chen $\mathrm{X}, \mathrm{Ba} \mathrm{Y}, \mathrm{Ma}$ L et al. Characterization of microRNAs in serum. a novel class of biomarkers for diagnosis of cancer and other diseases. Cell Res. 18(10), 9971006 (2008).

70. Hu Z, Chen $X$, Zhao $Y$ et al. Serum microRNA signatures identified in a genomewide serum microRNA expression profiling predict survival of non-small-cell lung cancer. J.Clin.Oncol 28(10), 1721-1726 (2010).

* Elegant example of the use of NGS for the analysis of miRNAs in serum of lung cancer patients. 
71. Keller A, Backes $C$, Leidinger $P$ et al. Next-generation sequencing identifies novel microRNAs in peripheral blood of lung cancer patients. Mol.Biosyst. 7(12), 3187-3199 (2011).

72. Meng W, Ye Z, Cui R et al. MicroRNA-31 Predicts the Presence of Lymph Node Metastases and Survival in Patients with Lung Adenocarcinoma. Clin.Cancer Res. 19(19), 5423-5433 (2013).

73. Nuovo GJ. In situ detection of microRNAs in paraffin embedded, formalin fixed tissues and the co-localization of their putative targets. Methods 52(4), 307-315 (2010).

74. Jorgensen S, Baker A, Moller S, Nielsen BS. Robust one-day in situ hybridization protocol for detection of microRNAs in paraffin samples using LNA probes. Methods 52(4), 375-381 (2010).

75. Wang $S$, Aurora AB, Johnson BA et al. The endothelial-specific microRNA miR126 governs vascular integrity and angiogenesis. Dev.Cell 15(2), 261-271 (2008).

76. Voortman J, Goto A, Mendiboure J et al. MicroRNA expression and clinical outcomes in patients treated with adjuvant chemotherapy after complete resection of non-small cell lung carcinoma. Cancer Res. 70(21), 8288-8298 (2010).

77. Nuovo GJ. In situ detection of precursor and mature microRNAs in paraffin embedded, formalin fixed tissues and cell preparations. Methods 44(1), 39-46 (2008).

78. Donnem T, Lonvik K, Eklo K et al. Independent and tissue-specific prognostic impact of miR-126 in nonsmall cell lung cancer. coexpression with vascular endothelial growth factor-A predicts poor survival. Cancer 117(14), 3193-3200 (2011).

79. Donnem T, Eklo K, Berg T et al. Prognostic impact of MiR-155 in non-small cell lung cancer evaluated by in situ hybridization. J.TransI.Med. 9, 6 (2011). 
80. Donnem $\mathrm{T}$, Fenton CG, Lonvik $\mathrm{K}$ et al. MicroRNA signatures in tumor tissue related to angiogenesis in non-small cell lung cancer. PLoS.One. 7(1), e29671 (2012).

81. Eilertsen M, Andersen S, Al-Saad S et al. Positive prognostic impact of miR-210 in non-small cell lung cancer. Lung Cancer 83(2), 272-278 (2014).

82. He L, Hannon GJ. MicroRNAs: small RNAs with a big role in gene regulation. Nat.Rev.Genet. 5(7), 522-531 (2004). 